\title{
The metropolitanization of Israel's settlement policy: The colonization of the West Bank as a strategy of spatial restructuring
}

\author{
Marco Allegra ${ }^{\mathrm{a}}$, Erez Maggor ${ }^{\mathrm{b}, *}$ \\ ${ }^{a}$ Instituto de Ciências Sociais, Universidade de Lisboa; Centro de Investigação e Estudos de Sociologia, Iscte - Instituto Universitário de Lisboa, Portugal \\ ${ }^{\mathrm{b}}$ Martin Buber Society of Fellows, The Hebrew University of Jerusalem, Israel
}

\section{A R T I C L E I N F O}

\section{Keywords:}

Political economy

Israel/Palestine

Metropolitanization

Settlements

State restructuring

West bank

Colonization

\begin{abstract}
A B S T R A C T
Israel's West Bank settlements are a central point of contention in the dynamics of the Israeli-Palestinian conflict. Overall, however, their rapid proliferation has been generally understood through the lens of an ideologically centered approach that highlights, specifically, the centrality of the national religious settlers' movement. Against this background, the article focuses on the overlooked reality of large, state-sponsored suburban settlements - and in particular on the role of the Israeli Ministry of Housing in their establishment between the mid1970s and the early 1990s. Building on contributions in the field of political economy and political geography, we conceive the actions of the Ministry in the occupied West Bank as a result of a broader strategy of spatial restructuring. By considering both economic and political imperatives underlying this strategy, our analysis offers a more comprehensive assessment of the factors behind Israel's settlement policy. Drawing on a broad range of empirical sources, from archival material to in-depth interviews with Israeli planners, we argue that the proliferation of settlements has been largely the outcome of a process of metropolitanization - i.e. of the dynamics of urban development of Israel's main metropolitan centers and the adoption of a new, post-Keynesian policy paradigm based on market-oriented economic development. This process has constituted a major factor for the settlements' growth and, ultimately, in the emergence and naturalization of a new territorial configuration in the area of Israel/Palestine.
\end{abstract}

\section{Introduction}

On October 12, 1982, a ceremony marking the official population of the new town of Ma'ale Adumim, - today one of the largest Israeli settlements in the West Bank, located only $8 \mathrm{~km}$ from the Old City of Jerusalem - was underway. The event's guests of honor, Minister of Housing and Construction David Levy and the ministry's DirectorGeneral Asher Weiner were accompanied by a group of reporters while they enjoyed a tour of the settlement's new homes and facilities. The construction of the first 700 residential units had already been completed, and another 2000 units were at an advanced stage of construction. Altogether, the projected plan of Ma'ale Adumim was comprised of 10,000 new residential units planned to house around 35,000 residents. Immediately following their tour, which included a visit to the new stone buildings, the commercial center, and the city's industrial zone, the Minister of Housing proudly declared that "Nothing can compare to the speed with which this modern city has been built," and added that "the laying of infrastructure, paving of roads, and provision of public utilities", with which the Ministry had been entrusted, will make it possible to "increase the rate of construction in Ma'ale Adumim as well as in other cities in Judaea and Samaria" (Avner, Yediot Aharonot, October 13, 1982: 23).

The ceremony held in Ma'ale Adumim represents just an episode in the over five-decade-long expansion of the Jewish settlements in the Palestinian West Bank - occupied by Israel during the 1967 War along with the Gaza Strip and the Golan Heights. The founding of Ma'ale Adumim, however, epitomizes many of the crucial features of Israel's settlement policy (hereafter ISP) as a whole: the establishment of several new planned towns in the regions of metropolitan Tel-Aviv and Jerusalem through large investments by the Ministry of Housing; the mobilization of state-of-the-art architectural and planning knowledge; and cooperation between the Ministry's planners and private developers. The construction of thousands of housing units in these settlements was part of a broader process of metropolitanization of Israel's spatial development policies and answered the growing demand for affordable housing among Israel's Jewish population. As a result, the

\footnotetext{
* Corresponding author. Martin Buber Society of Fellows, The Hebrew University of Jerusalem Mt. Scopus, Jerusalem, 919050, Israel.

E-mail address: erez.maggor@nyu.edu (E. Maggor).
} 
West Bank became one of the favorite destinations of young couples looking for quality housing at an affordable price right outside the increasingly crowded and expensive inner cities of Jerusalem and Tel Aviv. This influx of new residents marked the arrival of a diverse population into the settlements which dramatically altered their demographic composition. Unlike the homogenous national-religious population that characterized the settlement project during its early stages (Peled \& Shafir, 2002, pp. 165-172), the urban and metropolitan nature of these new settlements spawned a far more heterogeneous settler population than is often perceived. One that includes many secular and ethnically diverse families from different class backgrounds who had no previous connection with the religious-ideological settler movement. These included mizrahim (i.e., Jews of African or Middle Eastern descent), haredim (i.e. the so-called "ultra-orthodox Jews"), and immigrants from the former Soviet Union. Notably, these groups have become key participants in the settlement enterprise.

This paper examines Israel's settlement policy as a key engine for the process of "production of territory" (Brenner \& Elden, 2009) which reshaped the legal, economic, infrastructural, and symbolic geography of post-1967 Israel/Palestine. It applies a theoretical apparatus rooted in political geography and, more specifically, spatial political economy to understand how this process unfolded. This paper mainly focuses on the role of the Israeli Ministry of Housing (hereafter $\mathrm{MoH}$ ). Between the late 1970s and the early 1980s, the MoH assumed a key role in steering the development of ISP, which we conceive as a set of "territorial strategies", aimed at "mobilizing state institutions to shape and reshape inherited territorial structurations of political-economic life, including those of state institutions themselves" to "facilitate the production of the territory of the state, and often, in turn, that of the nation-state" (Brenner \& Elden, 2009, pp. 368, 369) vis-à-vis broad political, economic and social processes.

Our argument is twofold. First, our account shows that the ISP is at the same time the product of complementary factors, i.e. of its ideological and strategic drivers, as well as of wider socio-economic trends and of shifts in paradigms of territorial development. This paper focuses mainly on the importance of the latter in shaping the trajectory of the ISP and, ultimately, in consolidating the broad political legitimacy of Israel's control over the territories conquered in 1967. Second, we argue that our case study can contribute to wider theoretical debates in political economy and political geography. In this respect, the development of ISP serves as an example of the "historicity of the neoliberal state" (Hilgers, 2012) and of "variegated neo-liberalization" (Brenner, Peck, \& Theodore, 2010), showing how the homogenizing effects of global trends can coexist with and are reflected in, the heterogeneity of the local; and how the dynamic of state restructuring is inherently linked to local struggles for political legitimacy (Purcell \& Nevins, 2005).

The findings discussed throughout this paper draws on various empirical sources. These include original archival documents collected from Israel's State Archives, most of which were released as a result of this study. These materials pertain mainly to the $\mathrm{MoH}$ and document changes in settlement development policy in the first half of the 1980s. These sources are complemented by a dozen semi-structured interviews with Israeli planners, architects, and former senior officials from the $\mathrm{MoH}$ and Israel's other planning agencies carried out between 2010 and 2014. Finally, we supplement these data with official publications of the $\mathrm{MoH}$, historical and more recent newspaper articles, data collected by Israel's Central Bureau of Statistics, and numerous secondary sources.

Before going further, some clarifications on the terminology are in order. We use the terms "settlements" and "settlers" to refer to all the Jewish communities (towns, villages, neighborhoods) founded by Israel in the West Bank after 1967 and their inhabitants, including the socalled "new neighborhoods" built in East Jerusalem. In referring to the metropolitan regions of Tel Aviv and Jerusalem, many alternative definitions can be adopted (for Jerusalem see Allegra, 2013); our broad and somewhat flexible definition of "suburban settlements" refers to those relatively large communities (i.e. with a population of about 5000 residents or more) located within a range of 20-30 km from the inner cities of Tel Aviv (e.g. Ariel, Karnei Shomron, Alfei Menashe, Emmanuel) and Jerusalem, both inside (French Hill, Neve Ya'akov, Gilo, Talpiot, Pisgat Ze'ev, Ramat Shlomo, Har Homa) and outside its municipal borders (Ma'ale Adumim, Givat Ze'ev, Efrat, Beitar Illit, Geva Binyamin, Kokhav Ya'akov, Mod'in Illit) - see Fig. 1. A rough estimate would put the current number of settlers in the West Bank at around 650, 000 (out of a total Israeli population of some nine million), of which more than 200,000 reside in East Jerusalem (Allegra, Handel, \& Maggor, 2021).

\section{Israel settlement policy as a strategy of production of territory}

In the last two decades, many different scholars (Brenner \& Elden, 2009; Agnew, 2010, Painter, 2010 the special issue of Geopolitics 15:4) have tried to escape what John Agnew (1994) famously defined the "territorial trap" i.e. the ahistorical notion of territory which sees states as containers of specific sets of social and economic phenomena. Broadly speaking, this literature conceives territory as "necessarily porous, historical, mutable, uneven and perishable. It is a laborious work in progress, prone to failure and permeated by tension and contradiction. Territory is never complete, but always becoming" (Painter, 2010: 1094). Historically, new territorial configurations emerge from a process of "production of territory" (Brenner \& Elden, 2009; see also Allegra, 2013) developing across the dimensions of Lefebvre's triad of perceived, conceived and lived space. State territorial strategies, which mobilize "state institutions to shape and reshape inherited territorial structurations of political-economic life, including those of state institutions themselves" (Brenner \& Elden, 2009: 368), are typically a key factor in this process. The idea of territorial strategy, however, does not refer to a Weberian understanding of the territory as coinciding with (and homogeneous to) state space and rather emphasizes how territory emerges through a complex process of governance, in which state and non-state actors (Agnew, 2010; Ballvé, 2012) and socio-technical practices (Painter, 2010) play a crucial role. Following this line of thought, we examine ISP as a territorial strategy that has greatly contributed to reformulate the political geography of post-1967 Israel/Palestine - see also (Schwake 2021c).

In adopting an approach rooted in political geography and political economy, our work here and elsewhere (Allegra, 2013, 2016, 2017; Allegra, Handel, \& Maggor, 2017; Handel, Rand, \& Allegra, 2015; Maggor, 2015) follows several pioneering contributions on ISP between the mid-1970s and the late 1980s by Israeli geographers such as Yuval Portugali and David Newman, and by the late Meron Benvenisti and his associates in the West Bank Data Project (M. Benvenisti, 1976, 1984; Newman, 1985; M. Benvenisti, Abu-Zayed, \& Rubinstein, 1986; Newman \& Portugali, 1987; M. Benvenisti \& Khayat, 1988; E. Benvenisti, 1989; Newman, 1989; Portugali, 1991). This body of literature has been crucial in producing a first broad and holistic picture of ISP's origins, development, and long-term implications for Israeli-Palestinian relations (see also Demant, 1988; Harris, 1980; Lustick, 1988, 1993). Together with the numerous studies focusing on the settlers' movement and its influence on Israeli policymaking (Aran, 1991, 2013; Aran \& Feige, 1987; Friedman, 1992; Isaac, 1976; Newman \& Hermann, 1992; Sprinzak, 1991; Weisburd, 1989), this literature represents the bulk of scholarly contributions on ISP in the two decades that followed the war of 1967.

By the 1990s, however, the interest in the political geography and political economy of ISP had declined significantly. In the shadow of the Oslo process, the scholarly literature started to focus on the diplomatic and legal status of the settlements, while a growing number of local and international NGOs and agencies (e.g. Peace Now, B’Tselem, Bimkom, Human Rights Watch, the World Bank) began to systematically monitor the adverse impact of settlements' expansion on the welfare of the Palestinian population. The role of Israeli hardliners in the dynamics of 


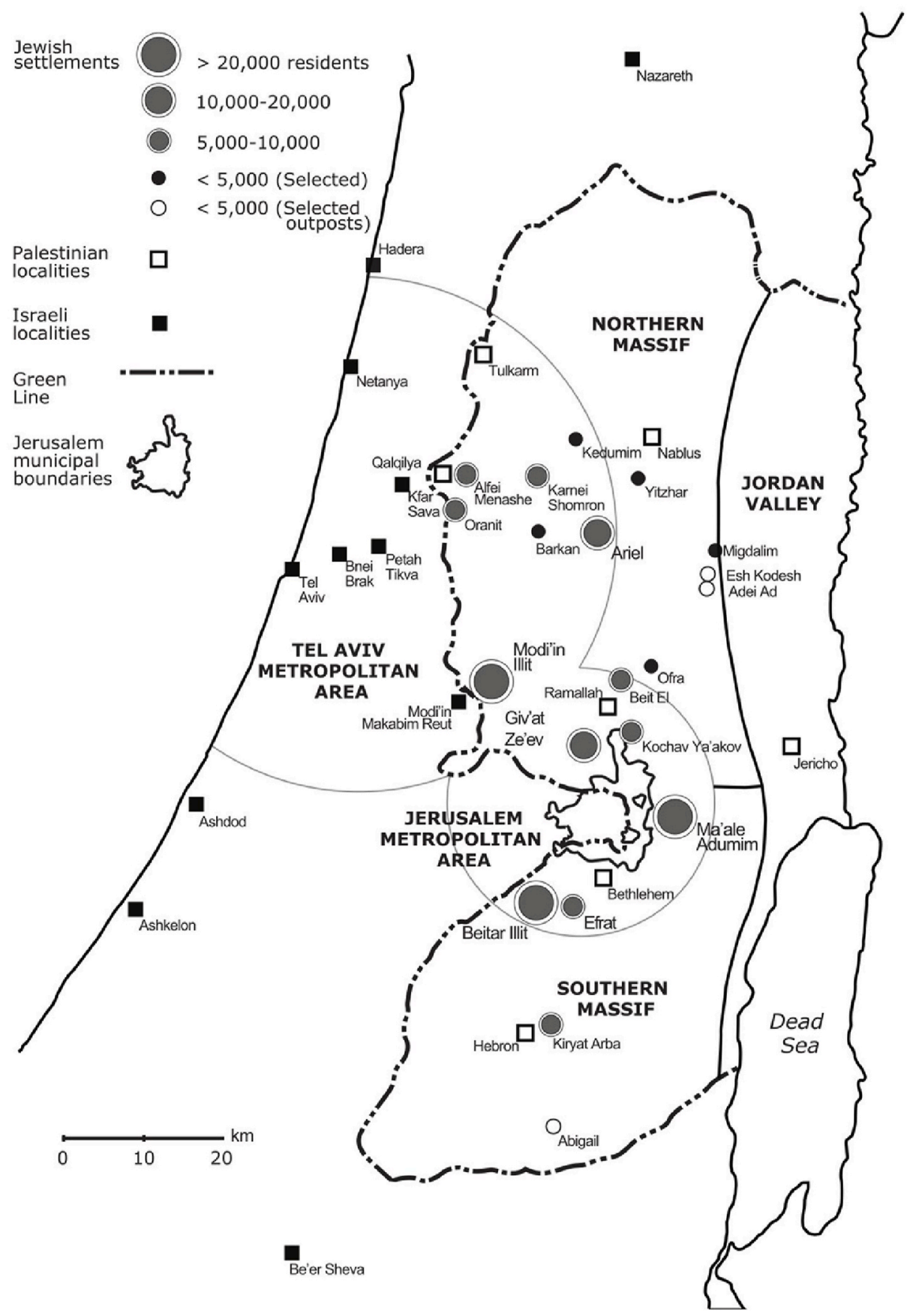

Fig. 1. Caption: Selected settlements in the West Bank. Source: (Allegra, Handel, \& Maggor, 2017): xii.

the peace process, however, continued to stimulate research on the more activist and ideological segment of the settler population (Elor \& Aran, 1995; Sivan, 1995; Feige, 2001, 2002, 2013; Pedahzur \& Perliger, 2009; Hirsch-Hoefler, Canetti, \& Eiran, 2016) and its influence vis-à-vis the Israeli establishment and political culture (Shahak \& Mezvinsky, 1999; Feige, 2009; Hirsch-Hoefler \& Mudde, 2020; Inbari, 2012; Pedahzur \& McCarthy, 2015; Taub, 2010).

All in all, this shift away from political geography and political economy contributed to flatten the image of the settler's population and attribute excessive emphasis to the agency of settlers' movement in Israeli politics (for a similar critique see: Allegra, Handel, \& Maggor, 2017; Dalsheim \& Harel, 2009; Weiss, 2009). In the last two decades, several studies have challenged the idea that the settlers' movement has been the primary engine of colonization, highlighting the role of the state as its main sponsor. Still, most have focused on the broader contexts of Israeli policies in the West Bank (e.g. Berda, 2017; Efrat, 2006; Gordon, 2008; Handel, 2014; Weizman, 2007) and of the dynamics of Israeli state-building and democracy (e.g. Peled \& Shafir, 2002; Shenhav, 2012; Yiftachel, 2006), while the relatively few contributions specifically addressing the ISP have instead followed established lines of inquiry by investigating the symbiosis between the settlers' movement and the government (Eldar \& Zertal, 2007; Gorenberg, 2006).

In the last few years, however, scholars have started to considerably broaden their analysis of ISP, focusing on the dynamics of the production of space (Schwake, 2021a, Schwake, 2020a, Schwake, 2021b; Shoked, 2020; Abreek-Zubiedat \& Nitzan-Shiftan, 2021; Rokem \& Allegra, 2016; Yacobi \& Pullan, 2014) on the heterogeneity of settlers population (Allegra, 2017; Allegra, Handel, \& Maggor, 2017; Dalsheim, 2011; Harel, 2017; Hirschhorn, 2017), including studies on the haredi 
settler community (Rubin, 2015; Cahaner, 2017; Shoked, 2019); on the political economy of settlements' proliferation (Allweil, 2020; Maggor, 2015; Schwake 2020c; Schwake 2021c) and the labour relations with the Palestinians employed in the settlement's economy (Farsakh, 2005; Paz-Fuchs \& Ronen, 2017; Vickery, 2017; Siegman, 2018); on the environmental and infrastructural dimension of colonization (Braverman, 2021); and on the process of banalization of Jewish presence in the West Bank (Allegra, Handel, \& Maggor, 2017; Weiss, 2017), including deliberate settlers' strategies in this respect (Grosglik, Handel, \& Monterescu, 2021; Handel, Rand, \& Allegra, 2015; Isaac, 2018; McGonigle, 2019; Monterescu \& Handel, 2020).

This paper builds on this recent growing body of literature. Through the paper, we argue that the lack of a specific focus on ISP as a state territorial strategy leaves several key questions unanswered: which factors account for ISP's success in transforming the geography of Israel/ Palestine? Why did certain settlement patterns prevail over others? And finally, how can we reconcile the inherently ideological and ostensible strategic nature of Israel's colonization of the West Bank with its mundane character and its appeal to non-ideological, run-of-the-mill Israelis?

Against this background, adopting a state restructuring perspective to observe the ISP presents two advantages. First, the literature on state restructuring provides us with a general theoretical argument about the spatial and territorial nature of states, showing how states deploy "spatial strategies" on several different scales to "regulate, produce and reproduce configurations of social space" (Brenner, 1997, p. 280). At the same time, this literature is sensitive to the dynamics underlying the construction of local political legitimacy (see e.g. Pullan \& Yacobi, 2017; Purcell \& Nevins, 2005). The literature on state restructuring allows us to conceptualize the dynamics underlying the development of the ISP at the intersection of space, economy, and politics, and across different scales (global, national, local); to chart the interactions of many actors, both state planners, and private developers, as well as the various settler groups, across different governance arrangements; and to observe the dialectic between spatial policies and the inherited configuration of the physical and human landscape. In turn, we argue that post-1967 Israel/Palestine represents a good case study to develop a clear sense of the relations between states, space, and territory. Mere reference to "Israel/Palestine" alludes to a set of questions that can hardly be answered without conceiving territory "at once as a historically specific form of politico-spatial organization, as a key modality of modern statecraft and as a strategic dimension of modern politics" (Brenner \& Elden, 2009, p. 356).

Second, this literature provides us with an empirical and historical description of the global process of neo-liberalization, which some authors have defined in terms of a transition from the post-WWII "Keynesian Welfare State" to a new, neoliberal "Post-Keynesian Competition State" (Brenner, 2004; Brenner, Jessop, Jones, \& MacLeod, 2003; Cerny, 1997; Jessop, 2002). The concept alludes, among other things, to the transition toward a more market-oriented paradigm of economic development and welfare retrenchment; from "government to governance" and toward a more entrepreneurial stance in the public administration at the urban level (Harvey, 1989); toward the "metropolitanization" of the national planning systems (see e.g. Brenner, 2004). Israel's political economy has followed a similar trajectory. During its first decades of existence, from its establishment in 1948 until the late-1970s, the Israeli state exerted a great deal of centralist control over matters of infrastructure and industrial development, foreign trade, economic investment, and the structuring and management of the labor market (Grinberg, 1991; Levi-Faur, 1998; Maggor, 2021). Israel's welfare state in this period was relatively robust, yet assured differential levels of decommodification to different social groups defined by ethnicity, nationality, and citizenship. This is because its origins, and important aspects of its continuing development, can be traced to the struggle to establish a Jewish presence in Palestine and to build up its territorial, demographic, and political base (Rosenhek, 1999; Shalev,
1992). Starting in the late 1970 s, much like everywhere else in the world, Israel's embarked on a deep and far-reaching process of economic restructuring. This shift encompassed the implementation of neoliberal formulas that included: the deregulation of the labor market; liberalization of financial markets; lifting of restrictions on the movement of capital and goods; heightened involvement of foreign capital; privatization of public infrastructure and assets; a dramatic decline in unionization and the decentralization of wage bargaining, and restrictive fiscal and monetary policies (Bassat, 2002; Kristal, 2013; Maron \& Shalev, 2017; Paz-Fuchs, Mandelkern, \& Galnoor, 2018; Shalev, 1998). It is often assumed that such neo-liberal reforms mark the retreat of the state from its historical position in the economic field (e.g. Fourcade-Gourinchas \& Babb, 2002; Prasad, 2006). Other studies, however, describe state action in the neoliberal era not in terms of more or less state involvement in the economy, but rather as the qualitative change in the state's mode of involvement and institutional configuration (Campbell, 2004; Maman \& Rosenhek, 2012; Weiss, 1998). As we will show in this paper, the same can be said regarding Israel's spatial development policies, particularly (but not exclusively) in regards to ISP and the role of the $\mathrm{MoH}$.

\section{The political economy of Israel's settlement policy}

In an article published in 1998 in the Annals of the American Academy of Political and Social Science, Arie Shachar, one of the foremost Israeli planners and urban geographers, observed that "settlements established in the West Bank and Gaza Strip were rarely regarded [by Israeli planners] as an extension of the existing settlement system of Israel" and "their location and size were not determined according to accepted planning principles" (Shachar, 1998, p. 218). In his article, Shachar expressed the widely held notion that ideological and strategic considerations represent the only link between Israel and the settlements, which otherwise exist in a separate administrative, socioeconomic and political space (Allegra, Handel, \& Maggor, 2017).

Contrary to this typical view, we wish to make two arguments in the following sub-sections. First, that the development of ISP has been consistent with broader changes in Israel's spatial strategy between the 1970 s and the 1980s, implemented as part of a larger shift from a Fordist/Keynesian model to a post-Fordist/neoliberal one outlined above, which emphasized endogenous factors as the primary driver of territorial development policy. Thus, the policy of the MoH in the West Bank reflected this shift in their emphasis on metropolitan consolidation, and in the idea that the government should use public policy to mobilize the energies of the private sector. Second, that the "metropolitanization" of ISP has constituted a key vehicle for the consolidation of the political legitimacy of Israel's control over the West Bank vis-à-vis a much wider Israeli audience than that of the political-ideological constituency of "Greater Israel".

\subsection{A paradigm shift in regional development strategies: from "Keynesian" to "post-Keynesian" settlement policy}

The post-war Keynesian model of state management was by and large based on the "correspondence between the national economy as the primary object of economic management, and the nation-state as the primary political scale on which economic management was conducted and social welfare was delivered" (Brenner, Jessop, Jones, \& MacLeod, 2003, p. 4). In parallel, regional development policies were designed to achieve spatially balanced economic growth, with public authorities investing considerable resources for the development of economically peripheral areas.

The original outlook of Israeli planning policies starting in the 1950s largely aligned with these global trends. National development policies were aimed at reaching a more balanced spatial distribution, socioeconomic regional integration, and dispersal of the industry to the peripheral regions. The goal of these efforts was to foster the development 
of Israel's peripheries and redistributing productive capacities evenly across the national territory. A core principle in this respect was the idea of "population dispersal". The most well-known examples of population dispersal were the so-called "development towns", built in the Galilee and the Negev regions during the 1950s under the auspices of the Sharon plan (Efrat, 1988; Shachar, 1971). The same logic guided the era's industrial policies, which provided generous state subsidies to manufactures that were willing to operate in peripheral regions. These policies had a significant effect on the national pattern of capital investment, infrastructure, housing, and public services (Shachar (1998), p. 213; see also Gradus, Razin, \& Krakover, 1993; Levi-Faur, 1998; Maggor, 2021). This approach was also initially applied after 1967 in the conquered territories. Examples include the Allon plan, which stressed the creation of small agricultural settlements along the Jordanianian border (Hasson \& Gosenfeld, 1980), the early establishment of settlements in the Gaza area, and the grandiose plans for the nearby port town of Yamit (Abreek-Zubiedat \& Nitzan-Shiftan, 2020, 2021), and through the settlement activity inspired by the territorial maximalism of movements such as the national-religious Gush Emunim or influential politicians like Ariel Sharon, which supported the establishment of settlements in relatively remote sites to strengthen frontier areas (see Benvenisti \& Khayat, 1988, pp. 99-104).

Starting with the mid-1970s, in the context of a global crisis in the world economy, this model began to be replaced by the new, postFordist model of the "post-Keynesian competition state". State spatial planning became increasingly fragmented, and no longer presumed that economic growth could occur in a geographically equilibrated manner. The regional policy was no longer oriented towards the even redistribution of productive capacities across the national territory, but rather towards the "preservation and development of 'endogenous" regional and urban growth potentials" (Brenner, 1997, p. 281).

The same shift took place in Israel in the same period (Schwake, 2020c, 2020b). Since the mid-1970s, Israeli planners abandoned the principle of population dispersal in support of an approach that emphasized the concentration of economic activities in a limited number of core areas, and the provision of the infrastructures needed to lay the ground for market-oriented development. It was in this context that new towns such as Modi' in (located about $30 \mathrm{~km}$ from both Tel-Aviv and Jerusalem) were erected and that the massive expansion of existing localities such as Rosh HaAyin and Rishon Lezion (within the metropolitan region of Tel Aviv) or Beth-Shemesh (about $30 \mathrm{~km}$ from Jerusalem) took place. This outlook found its ultimate expression in the national statutory and strategic plans approved in the 1990s, more specifically the National Master Plan (NMP 31), which was published and approved by the Israeli government in 1992, and the Israel 2020 plan, which was completed in 1997 (see Razin, 1990; Shachar, 1998). In this respect, the creation of large suburban settlements in the West Bank was coherent with the abandonment of previous models of "population dispersal" in favor of an approach based on the potential for "endogenous" growth and the intrinsic advantages of location, and a market-oriented logic of development emphasizing economic rationality, efficiency, and feasibility, metropolitan consolidation. As Gabriel Schwake (2020a, 2021c) has recently shown, these new policies of territorial development were deployed on both sides of the Green Line. This new phase of Israel's settlement policy had therefore unique features that differentiate it from earlier Israeli and Zionist spatial development models (see e.g. Benvenisti, 1984; Schwake, 2020c), and did not represent the mere continuation of previous trends. Indeed, at least to a certain extent, these developments run counter to preferences for "ideological", "agricultural" or "strategic" models of settlement - which preferred the establishment of new communities in relatively remote locations (Maggor, 2015). Whereas these various settlement models did persist after the 1980s, and still exist to this day, the suburban model we focus on in this paper has remained the leading force behind the continued expansion of the settlement enterprise.

\subsection{Settlement policy as metropolitan consolidation}

The West Bank offered vast resources for this reorientation of Israeli spatial and development policies. The area constituted, from a planning point of view, an ideal reservoir of land for the metropolitan expansion of Tel Aviv and Jerusalem and particularly in the light of the growing demand for affordable and quality housing (Benvenisti, Abu-Zayed, \& Rubinstein, 1986; Gonen, 1995; Portugali, 1991) - a need which had been exacerbated by the retrenchment in public spending on housing in Israel proper (Carmon, 2001). The existence of such spatial and economic potential was not lost on senior bureaucrats in Israel's MoH. In 1982, an internal committee in the $\mathrm{MoH}$, appointed by the director-general of the ministry, Asher Weiner, recommended concentrating development efforts in settlements with high-growth potential located in the metropolitan belt of Tel Aviv. The settlements of Ariel, Karnei Shomron, Alfei Menashe, and Emmanuel were chosen "in view of their location and power of attraction," while remote localities with "low development potential" remained under the control of the rural administration (November 1982, Israel State Archive, thereafter ISA, ISA/GL 109/14903/1).

The principles and vision guiding the MoH's decision were outlined most clearly by Asher Weiner. Speaking at a plenary session of the annual meeting of the Israeli Geographical Association on December 7, 1983, the MoH's director-general explained that one of the main reasons for which the Ministry regarded the West Bank as a preferred area for development was the "proximity of certain parts of the region $[\ldots]$ to the greater Tel Aviv metropolitan area". As for "the distribution of development in the region", he explained that instead of developing "as many settlements as possible which [...] will be small," and "relatively expensive to establish and maintain", the MoH preferred "the establishment of larger, relatively few urban settlements that would be costeffective by establishing a system of services [...] with a relatively low per capita cost of maintenance." A similar logic was followed with regards to the issue of employment centers. In this regard, relying on already existing employment centers in the core regions of Israel Proper permitted the $\mathrm{MoH}$ to focus its efforts mainly on the development of residential areas. In his talk, Weiner outlined in great detail the MoH's vision for the "development of several urban centers [...] in which thousands of people will live within the next twenty years." These, he explained, will serve as "large hubs" that would enjoy "comprehensive development" along with "a national and regional infrastructure system" that would ensure "a high level of services", and would be integrated with "Israeli centers of activity" in the already developed cities within the Green Line (December 1983, ISA/RG 109/GL/14616/8).

In the case of Jerusalem, the metropolitanization of the settlement policy had been anticipated in the early 1970s by the Israeli plans for the "new neighborhoods" built in the newly expanded municipal boundaries of the city - which included about $70 \mathrm{~km}^{2}$ of West Bank territory (compared to the $6.5 \mathrm{~km}^{2}$ of the former Jordanian municipality). Since the annexation of East Jerusalem in 1967, the MoH and the government had pursued a model of "dispersed" urban development (Faludi, 1997; Schweid, 1986) based on the construction of the first belt of satellite neighborhoods (Ramat Eshkol, French Hill, Neve Ya'akov, Gilo, Talpiot, Ramot). In the 1970s, two new development plans - "satellite town north" and "satellite town south" (later renamed "Mevohot Adumim" and "Mevohot Etzion", respectively) - were prepared by the ministry to extend the metropolitan region of Jerusalem both northward and southward while using new settlements (Geva Binyamin, Kokhav Ya'akov, Beitar Illit) to create a "significant territorial extension" of the city's outer circle. These plans aimed not only to strengthen the Jerusalem region but to integrate it with the central region of the state using three new central arteries (interview with the MoH's former Head of Programs Department, February 2012). The birth of Ma'ale Adummim, Givat Ze'ev, and Efrat outside the municipal borders - as well as later development in the $1980 \mathrm{~s}$ - followed the same pattern. Indeed, senior planners of the $\mathrm{MoH}$ describe the various phases of development around the 
city's core in terms of an overall process of strengthening of a metropolitan region through the creation of a Jewish hinterland east of the city (interviews with the director of the MoH's Department of Development Programs, Jerusalem District, November 2010 and former Head of the Program Department, February 2012; see also Shlay \& Rosen, 2010).

Vast amounts of government resources were therefore channeled to the region through the $\mathrm{MoH}$ to foster urban and regional development and integrate selected areas of the West Bank into Israel's core regions. In 1984, the annual public expenditure in the region almost tripled (Benvenisti, 1986, p. 56) and so did the amount of housing construction (February 19, 1980, ISA/GL 109/8325/4; October 2, 1985, ISA/GL 109/14616/11). In 1984 the West Bank region enjoyed the largest concentration of publicly funded housing construction in the entire country, with a rate of almost $30 \%$ of the total public construction (Benvenisti, 1986, p. 52). This figure was a result not only of the increasing investment in the region but of the decline in investment in housing and construction in the state's peripheral regions - a direct consequence of the state's abandonment of the principle of population dispersal and balanced spatial distribution. While the data above refers to the West Bank as a uniform region (excluding East Jerusalem), a closer analysis of the allocation of resources highlights the disproportional investment of public resources in settlements located in the metropolitan areas of Tel-Aviv and Jerusalem. A summary of construction data for the years 1979-1984 (once again, excluding East Jerusalem) shows that out of 11,000 new residential units built in the settlements during this period, 8000 (73\%) were located in areas of high demand near Tel-Aviv or Jerusalem (ISA/GL 109/8325/4; ISA/GL 109/14616/11).

A large part of the MoH's budget was allocated for the construction of the infrastructure needed to create and maintain a single metropolitan network. For example, in 1983 more than half of the total spending on "infrastructure in preparation for construction and population of new settlement neighborhoods" was allocated to four large settlements located in the Tel-Aviv metropolitan (Alfei Menashe, Immanuel, Ariel, and Karnei Shomron) and two large settlements located just outside Jerusalem (Ma'ale Adumim and Givat Ze'ev; Kiryat Arba, near Hebron, was also included in the list; ISA/GL 109/14674/4). The largest investment was directed to fund the planning and construction of an intercity highway system, meant to provide "rapid, secure access" from urban centers in the West Bank to employment and commercial areas located in the coastal plain and Jerusalem (December 1983, ISA/GL 109/14616/8). Examples of these arteries were the Trans-Samaria highway (Road N. 5, today one of Israel's largest highways cutting through the West Bank and the $6 \mathrm{~km}$ highway linking Ma'ale Adummim to Jerusalem). The following decades have seen even larger investments in roads, as hundreds of kilometers of secure highways now link settlements to Israel proper, further incorporating the settlements to Israel's heartland (Gourji \& Bassok, 2003; Shezaf, 2020).

The result of this paradigm shift is visible forty years later. Metropolitanization paved the way for bringing tens of thousands of Israeli Jews into the West Bank. By 1985, the population concentrated in urban blocks in proximity to the Green Line accounted for close to 75 percent of the entire settler population residing in the West Bank outside Jerusalem (Benvenisti, 1987: 47), a figure that eventually climbed to 80-85 percent and has remained constant to this day (Allegra, 2013, 2016). Indeed, already in 1991 the Israeli geographer Juval Portugali noted that the Jewish colonization of the West Bank had been "mostly part of the metropolitan expansion of the Tel-Aviv region and the metropolitanization of Jerusalem" (Portugali, 1991, p. 33; see also Allegra, 2013; Newman, 1996; Newman \& Portugali, 1987). Needless to say, the fact that suburban settlements were built "in view of their location and power of attraction", and with the goal of "metropolitan consolidation" did not make things any better for the Palestinian population. On the contrary, the development of settlements such as Ariel or Ma'ale Adumim has proved to be especially harmful to the territorial contiguity of Palestinian areas (including access to Jerusalem) and for the prospect of a "two-state solution" to the Israeli-Palestinian conflict. More broadly, residential, and infrastructural construction has imposed significant barriers on the development of Palestinian communities and constitutes a single "gating complex" (Handel, 2014) that severely limits Palestinians' access to land and resources.

\subsection{Settlement policy and public-private partnerships}

The policies of the MoH were directed not only to individual settlers but also to the Israeli business community; indeed, the creation of public-private partnerships was one of the main tenets of the new policy paradigm. Nowhere was this new balance of state-market relations more widespread than in the realm of housing development. Whereas in the context of Fordist, spatial-Keynesianism the state both provided the necessary capital and carried out the lion's share of development efforts (Carmon, 2001; Gradus, Razin, \& Krakover, 1993; Shachar, 1998), these new development strategies involved a diminished role for the state in the realm of actual construction, but a more significant role in incentivizing private capital investment by planning, providing subsidized mortgages and tax breaks, as well as in upgrading infrastructures (Carmon, 2001; Maron, 2015). In this period, in line with the direct, supply-side spatial tactics of post-Keynesianism, key state agencies such as the $\mathrm{MoH}$ began establishing partnerships with leading contractors, real-estate investors, and first-tier construction firms, to foster urban and regional development in targeted areas (Margalit, 2014).

The West Bank was no exception in this sense. Following the successful involvement of private-sector construction firms in the development of settlements in East Jerusalem (Yacobi \& Pullan, 2017), in the early 1980s government planners believed that other "areas of high demand" in the West Bank were now also "ripe for an increased share of private capital investment" (Benvenisti, 1984, p. 56). In a letter endorsing public-private partnerships addressed to the prime minister, the finance minister, the minister of housing, and the MoH's director-general, Deputy Defence Minister Mordachi Zippory commented that: "the extensive involvement of private construction firms [in the West Bank]" could contribute to "relieving the burden of state agencies and resources in the advancement of such important national [development] projects", and "provide momentum for developing the peripheral areas of both the coastal plain and Jerusalem metropolitan areas" (1981, ISA/GL 109/14616/8). In a memorandum sent to the Minister of Housing David Levy and the Director-General of the MoH, Asher Weiner, on September 3rd 1981, Yossi Margalit, the managing director of the Rural Construction and New Settlements Administration wrote: "There is great interest in the part of entrepreneurs, construction firms and other agencies [...] in the allocation of land for construction [in the new settlements]". "To the extent that the conditions for assistance in place today are guaranteed," he added, "[it will be possible] to expand construction [in the region] far beyond its current scope" (ISA/GL 109/8487/10). Indeed soon, most government incentives to private construction firms, such as dramatically low land prices (only five percent of the estimated land value, compared to eighty percent in Israel proper) - offered across the West Bank but most valuable in areas of high demand - were introduced and institutionalized in official government decisions (ISA/GL 109/14616/9; see also Ha'aretz, December 6, 1982, p. 9).

In 1983, Minister of Housing David Levy could declare in an interview to Yedioth Aharonoth that the $\mathrm{MoH}$ was in the midst of a "large, silent revolution" which consisted mainly of "getting private firms and entrepreneurs to invest private capital, alongside investment from the government". This approach confirmed the minster, "has already proved itself [successful] in the settlements of Ma'ale Adumim, Ariel, Emmanuel, Efrat, Karnei Shomron, Givat Ze'ev, Alfei Menashe," - all located in the West Bank's areas of high demand (Yediot Aharonot, January 14, 1983, p. 8). In the same vein, in 1983 Weiner expressed the MoH's desire to provide "assistance" and "subsidies" to construction firms and private 
developers who will come to build in these areas (December 1983, ISA/ RG 109/GL/14616/8).

More subtly, this partnership also inaugurated a qualitative shift in the division of labor between state and market. In the early 1980s, the public participation ratio in planned investments in the region (1983-1986) was estimated at $60 \%$ of the total capital investment. A closer look, however, illuminates crucial aspects of this new division of labor: while public spending still funded the majority of "settlement infrastructure" (62\%), "industry" (73\%), "community services" (73\%), and the entire cost of "roads, water, and communications", private capital funded the majority (67\%) of housing construction (Benvenisti, 1984, p. 56). In other words, while public-private cooperation still required significant public funding and involvement, it allowed the state to take a secondary role regarding funding the actual housing construction, as most of the capital investment needed was provided by the private sector. This new division of labor allowed the state to relieve the burden of fully funding all development efforts in the settlements - thus more easily abiding neo-liberal prescriptions for "fiscal responsibility" while still maintaining relative autonomy and control over the general process. As the former head of the Programs Department in the $\mathrm{MoH}$ explained, the MoH's control over the general planning stages and the construction of the preliminary infrastructure "without which, no new neighborhood could be built" allowed the state to retain the final say regarding all new development efforts (interview with the former head of the MoH's Programs Department, February 2012).

The state's financial and institutional support of settlement development in prime, high demand areas, was intended not only to produce new, affordable housing as argued above but also to address problems of capital accumulation that concerned the private construction sector (Allweil, 2020, p. 79; Maggor, 2015, pp. 153-154). Indeed, given the set of favorable conditions provided by the government, it is not surprising that these new public-private partnerships were also enthusiastically endorsed by leading members of the private sector. One of the strongest advocates of this policy was David Stern, a former right-wing politician turned businessman. In an interview marking his new appointment as President of the peak organization of Israel's real-estate sector, Stern referred to the West Bank as "a large reserve of land" and acknowledged that "the blessed activity carried out in this area [by the government] had $[\ldots]$ opened the way for large scale settlement of hundreds and thousands of new families in The West Bank." (The Contractor and Builder, issue 213, August 1982). All in all, state investments in the West Bank had an unprecedented influence on sales made by private construction firms, to the point that in 1984 the newspaper Yediot Aharonot could conclude that "construction beyond the Green Line had saved the building sector from a serious crisis", and that "were it not for building in [the West Bank], a market that most private companies have penetrated this year - we would have witnessed a housing crisis of unprecedented proportions" (Yediot Aharonot, 1 January 1984, p. 18).

\subsection{Settlement policy as a vehicle of political legitimacy}

We have detailed so far how the trajectory of the ISP has reflected some key paradigmatic shifts in Israel's territorial development strategies - from a Fordist/Keynesian model to a post-Fordist/neoliberal one. The literature on state restructuring, however, also alerts us that, in any process of state rescaling, state actors must also "reproduce the political legitimacy of the power relations between ruler and ruled", as "[c]itizens' political support is [...] conditioned by a contingent, differentiated, and changing set of expectations[, and] the state must meet some combination of those expectations sufficiently to maintain the overall political support of citizens" (Purcell \& Nevins, 2005, p. 216). Given the controversial character of Israel's control of the West Bank (and its considerable, long-term implications for the Israeli society), we might therefore ask: how did the ISP contribute to reproducing the political legitimacy of the state vis-à-vis the expanding Jewish presence in the territories occupied after 1967?
The literature on Israel's settlement policy (and indeed, most of the contributions on the spatial and territorial side of Israeli policies in the West Bank) has traditionally emphasized the ideological component of ISP's legitimacy. To be sure, influential sections of Israeli society and key members of the political establishment had always regarded Israel's control over the West Bank as the fulfillment of Zionism's historical trajectory, and a strategic asset for the defense of the territorial integrity of the state (as in the logic of "defensible borders"). After 1967, Israel's decision "not to decide" (Ranta, 2015) on the future of territories opened therefore a window of opportunities for the advocates of "greater Israel" to call for an aggressive expansionist agenda in the West Bank and channel significant public resources into the colonization of the West Bank. We argue, however, that ideological and security imperatives were essential but insufficient in fully legitimizing the proliferation of settlements before the wider Israeli public. In this respect, the "post-Keynesian" and suburban character that the ISP assumed in the late 1970 s and early 1980s represents a crucial factor in bringing on board sectors of the Israeli society that had been largely uninterested in the religious-nationalist or strategic value of colonization; and in forging broad coalitions of actors in support of settlements proliferation. Without the growing support of these constituencies, we argue, it is hard to imagine that the settlements would have grown to their current size or enjoy the kind of legitimation they receive from the Israeli public. This is especially true regarding the large 'settlements blocs', where most of the settler population resides and around which there is strong public consensus.

A first and rather obvious vehicle for enhancing the legitimacy of the ISP has been represented by Israel's huge investments in the West Bank, e.g. through subsidized mortgages, infrastructures, and services. ${ }^{1}$ The role of the Israeli state as a major financial sponsor of the settlements has been widely recognized (Efrat, 2006; Hever, 2010; Peled \& Shafir, 2002). Yet, this involvement is usually interpreted simply as a strategic device used to advance ethnonational or strategic imperatives with economic means. While there is, of course, an element of truth to this view, it is not in itself a sufficient explanation as to why the settlements became such an attractive location for the broad Israeli population. The emergence of a broader political consensus around ISP depended to a large extent on the way subsidies could be ingrained into a new set of development policies based on the paradigm of endogenous growth and metropolitanization. As demonstrated above, this shift was a result of broader socio-economic and political imperatives such as addressing social demands for affordable housing and creating a new opportunity for profit-making for the private sector. Although subsidized mortgages and tax breaks were available throughout the West Bank, suburban settlements were particularly attractive for large numbers of ordinary Israelis and the real-estate industry, insofar as the significant financial and fiscal benefits added to their decisive locational advantages - a condition that David Newman appropriately termed "double centrality" (Newman, 1996). Especially since the 1980s, the government also encouraged industrial development in the occupied territories. All

\footnotetext{
1 Starting in the 1980s, the MoH heavily subsidized housing costs in the settlements. In June 1982, for example, a plan to assist the "acquisition of apartments in urban and community settlements in [the West Bank]" was launched, offering subsidized loans and generous mortgage repayment schemes (June 1982, ISA/GL 109/14616/1). As a result of this plan, settlers enjoyed mortgages and grants between $30 \%$ and 50\% larger than what potential homeowners could receive in developing towns within Israel. Together with subsidized land prices for contractors, these benefits resulted in potential buyers enjoying significantly lower prices in the settlements, when compared with similar apartments in developed Israeli cities like Jerusalem, Kfar-Saba or Petach-Tikva. During this period, the $\mathrm{MoH}$ also funded the construction of many public institutions including: schools, kindergartens, synagogues, daycare centers, community centers, as well as various infrastructure projects that included sewages, waterworks, electricity and communication lines (Maggor 2015).
} 
settlements, including those just a short drive to Tel Aviv or Jerusalem, were awarded an 'A' development zone status, entitling them to expanded benefits on par with localities in Israel's most remote periphery. These benefits were greatly attractive, particularly in industrial zones within commuting distance of the Tel Aviv metropolitan area. For example, the Barkan industrial zone, near the town of Ariel, became a major magnet for publicly supported industrial investment in Israel (Gradus, Razin, \& Krakover, 1993, p. 226-227). Attractive housing opportunities remain to this day an important catalyst to inward migration to West Banks settlements, particularly those located in the Jerusalem and Tel Aviv metropolitan areas. In fact, a recent study (Ben-Shahar, Gabriel, \& Golan, 2019) has found that, in the period 2000-2015, economic factors remain salient in households' determination of relocating to the West Bank regardless of religious belief or ideological orientation, and that the price gap between identical housing units in Israel and the West Bank remains substantial.

A second vehicle for ISP's political legitimacy was represented by its demographics. As we have seen, the "double centrality" of suburban settlements attracted tens of thousands of Israeli to the West Bank. Furthermore, as Daniel Gutwein has argued, large investments beyond the Green Line became a compensatory mechanism that supplied "partial substitutes to the commodified services that [Israel's lower classes] could not afford [in Israel proper]" (Gutwein, 2004), and whose relative size in the population was gradually increasing (Dahan, 2002; Kristal, 2013). Starting in the 1980s, and throughout the last three decades, a growing number of Israel's most marginalized groups found refuge in the settlements. Indeed, recent scholarship has found the settler population includes the large number of mizrahim (i.e. Jews of African or Middle Eastern descent, Dalsheim, 2008; Gillis, 2009), haredim (i.e. the so-called "ultra-orthodox Jews", (Cahaner, 2017; Rubin, 2015), and immigrants from the former Soviet Union (H. Weiss, 2011). The process of rapid expansion of Israel's metropolitan centers into the West Bank made the settler population more diverse in terms of ethnicity, religiosity, political orientations, and more broadly reflective of Israeli society. With time, these groups not only became the main clients of ISP but also provided the political support required for maintaining it. This was carried out both locally, through the leadership of municipal authorities, and on a national level, through these groups' representative parties in parliament - for example Shas and Yahadut Hatorah for the mizrahi and haredi population, or Yisrael Beiteinu for immigrants from the former Soviet Union.

The diversity of the settler population hints at a third, key factor of ISP's political legitimacy, i.e. the fact that suburban settlements became the territorial platform for the establishment of broad coalitions of actors supporting the ISP. The early settlement models had resulted in the creation of relatively small and homogeneous communities, such as the socialist kibbutzim and the national-religious yishuv kheilatim, which served the purpose of the "redemption of the land" and catered to a relatively restricted public of committed pioneers. Suburban settlements, on the contrary, constituted at the same time a vehicle of upward social mobility; an appropriate planning answer to the overcrowding of inner cities; a channel to effectively allocate public resources destined to the West Bank; and an expanding, profit-making business enterprise. Each of these rationales for suburban colonization appealed to specific constituencies and groups (e.g. the poor, the upwardly-mobile middle class, the business community, civil servants and planning professionals, etc.; see e.g. Schwake, 2020b, Schwake, 2021c); each contributed to strengthen the consensus around ISP and make it relatively non-controversial (Allegra, 2013; Allegra \& Handel, 2017). Many of these groups were not interested in the ideological value of colonization and looked at the settlements in purely financial-logistic terms, or as gated safe spaces, which protect and preserve a community of peers (Allegra, 2017; Yiftachel, 2003). For some, such as the haredim, the whole concept of colonization had long been dangerously near to religious anathema - at least until some key features of suburban colonization (e.g. affordability, proximity to main haredi religious and communal centers, opportunities for self-segregation) brought them to move en masse to the West Bank. As a result, haredi parties have shifted their position regarding the future of the settlement enterprise. Indeed, as Lee Cahaner has shown, while the haredi population did not arrive at the $\mathrm{WB}$ as ideological supporters of the settlements; their growing involvement in the ISP has been paralleled by the embrace of territorial maximalism similar to the traditional position of the national-religious right (Cahaner, 2017, see also: Gordon \& Cohen, 2012, pp. 12-14). In other words, while the underlying motivation for settling beyond the Green Line may well have been its urgent and growing need for affordable housing, this process has resulted in a general rightward turn of the haredi society.

Finally, the existence of suburban settlements greatly contributed to making the transition to the West Bank seamless for ordinary Israelis. While Israel's control over the West Bank remains problematic to this day for a considerable part of the Israeli public, very few Israelis would have considered any withdrawal from East Jerusalem even in the aftermath of the war; the proliferation of settlements in the city and its immediate environs was far less controversial - indeed, some have suggested that this is the reason why settlements in Jerusalem (the socalled "new neighborhoods") have remained by and largely invisible in the scholarly production on ISP (Abu-Lughod, 1982; Allegra, 2013). Infrastructural investments by the $\mathrm{MoH}$ resulted in the integration of large portions of the West Bank into the urban fabric of Israel's main metropolitan centers. Urban planning and architecture further contributed to the blurring the Green Line: consistently with contemporary development of housing policies throughout Israel (Carmon, 2001, pp. 194-195), these suburban settlements were the expression of a new, postmodern outlook based on the variety of spaces, the search for a local architectural language, and deeper integration between the built areas and the surrounding natural environment; and cutting-edge architectural and planning techniques were employed in the construction of suburban settlements (see e.g. Allegra, 2013, pp 499-503; Weizman, 2007, pp. 111-116 on Ma'ale Adumim; Yacobi \& Pullan, 2017 on French Hill). The result was that Israelis could live in settlements "did not look like settlements" (Kratsman \& Ginsburg, 2017).

\section{Conclusions}

Israel's settlement policy has represented a powerful engine of the transformation of the political geography of Israel/Palestine. This paper has made two distinct and interrelated arguments in this respect. In the first place, our analysis shows how settlement's expansion was part of a broader process of state restructuring, and a shift in the state's spatial development policies, from a nationally-oriented development model to a more targeted, and regionally focused metropolitan development outlook. The trajectory of the ISP was therefore intimately connected to the dynamics of development of Israel's main metropolitan centers, and contemporary trends toward marketization and suburbanization in the Israeli society and beyond. The ISP, in this respect, has not been an exceptional phenomenon contradictory to other trends in Israeli society - something happening (socially, politically, and geographically) "outside" Israel. In the second place, we have argued that this shift has greatly contributed to expanding the audience of (and the consensus around) the ISP, thereby strengthening the political legitimacy of Israel's control on the West Bank. As we have argued elsewhere (Allegra, Handel, \& Maggor, 2017) a key success factor of the ISP has been precisely its banal, mundane character, epitomized by the suburban settlements in the area of Tel Aviv and Jerusalem, which contributes to obscure the political nature of colonization and made it relatively non-controversial for broad sectors of the Israeli Jewish society.

Neither of these statements should obscure the fact that Israel's colonization of the West Bank remains an inherently political process: the development of ISP was made possible because the Israeli government decided to open the Palestinian territories to colonization after 1967, and because of the existence of a strong and influent current of 
territorial maximalism in Israeli politics. On the contrary, our study demonstrates that the neoliberal logic is not necessarily contrary to the pursuit of ethnonational goals (see also (Clarno, 2017; Schwake, 2021c; Weiss, 2011); rather, we argue that pragmatic choices are shaped by prevailing societal and economic imperatives have been paramount to the successful development of the ISP. We further argue that the metropolitanization of ISP, rather than depoliticizing colonization, has contributed to defining the "rules of the game" for successful strategies of settlement expansion. Finally, whatever the factors underlying the success of ISP, its consequences are inherently political, and will remain so for the foreseeable future: the colonization of the West Bank happens at the expenses of the Palestinian population, for whom the suburbanization of ISP further contributed to truncating the Palestinian metropolitan network centered on Jerusalem, and represents a continuous source of territorial conflicts and struggles. As Gordon and Cohen have argued, while violent actions tend to receive more media attention, the inflow of settlers from Israel to the West Bank represents in fact "the most insidious kind of unilateralism in the conflict" (Gordon \& Cohen, 2012, p. 11) because it undermines the possibility of a Palestinian polity.

At the same time, the study of Israel's settlement policy provides us with useful insights on current debates developing on the dynamics production of territory: i.e. on "how particular territorial settlements are produced, and how states operate in ways that normalize and perpetuate this spatial order of things" (Elden, 2010, p. 760) and of the political dynamics of state restructuring (Purcell \& Nevins, 2005). Our work on the ISP addresses three key dimensions of inquiry on territory (Brenner \& Elden, 2009): the multi-faceted nature of the production of territory; the deployment of state territorial strategies; and the "territory effect".

First, the dynamic and contested nature of territorial configurations in Israel/Palestine allows us to see the dynamic of the production of territory at work. It shows us how territory is a bundle of practices (e.g. the flow of settlers/commuters across the Green Line), abstractions (e.g. the paradigms of endogenous regional and urban growth as resulting in Israeli policy documents and maps), and material objects/infrastructures (e.g. the built structure of the settlements and their infrastructure); and how new territorial configurations emerge from the interaction between inherited and emergent geographies. In this respect, our work contributes to critical urban theory and the stream of settlercolonial studies (Yiftachel, 2016; Porter \& Yiftachel, 2019; see Barry \& Agyeman, 2020 for a review) by showing how parallel forces and discourses contribute to shaping the nature of urbanization, and especially, in this case, concerning the expansion of the metropolises of Tel Aviv and Jerusalem. Second, conceiving the ISP as a territorial strategy gives us a more comprehensive picture of the role of Israeli policymaking in reshaping inherited territorial configurations. It describes the key role of state institutions, such as the $\mathrm{MoH}$, as the center of gravity of the ISP, while at the same time showing how state strategies both accommodated and shaped other societal and economic imperatives through a variety of policy instruments and the mobilization of wider coalitions of actors. ${ }^{2}$ It describes its long-term drivers and consequences, but also points to its grey areas, its contested character, its incompleteness - indeed, the case of ISP shows how the production of territory does not necessarily imply the homogenization of state spaces, but can instead systematically rely on the production of difference (Ford, 1999): over more than five decades, the ISP has not created a new international border, but rather a patchwork of jurisdictions and special status areas. Third, the case of ISP is a particularly stark illustration of the "territory effect"- i.e., "the state's tendency, through its territorial form, to naturalize (at once to mask and to normalize) its own transformative, intensely patterning effects upon sociospatial relations" (Brenner \&

\footnotetext{
${ }^{2}$ Interestingly, as recent scholarship on Palestinian state-building has shown (Rabie, 2021; Tabar \& Al-Botmeh 2020), the production of Palestinian space has also adapted to the imperatives of global, neoliberal capitalism, for example in the case of the development of the new Palestinian city of Rawabi.
}

Elden, 2009, p. 354). The ISP has not only remodeled previous territorial configurations but also naturalized new ones, consolidating the political legitimacy of Israel's control over the West Bank. The establishment of suburban settlements has thus been paramount in bringing on board sectors of the Israeli population that did not necessarily partake the ISP's underlying strategic and ideological rationale.

Finally, it is only fair to recognize that this study is by and large limited to the examination of the Israeli side of the settlement equation, and specifically of certain drivers and mechanisms of Israeli policymaking in regards to the ISP. These limitations implicitly call for a significant extension of scope and breadth of the research on ISP; theoretically, through an engagement with other key contributions in the field of political economy and geography (e.g. on territorial competitiveness and locational policies, gated urban developments, and splintering urbanism); methodologically, through systematic data collection at a macro level as well as historical and ethnographic research; thematically, through the analysis of the socio-economic features of settlers population, the dynamics of political bargaining and patronage underlying the development of settlements, and their role as spatial interfaces between the Jewish and the Palestinian population of the West Bank.

\section{Declaration of competing interest}

None.

\section{Acknowledgments}

The authors rendered an equal contribution to the article. We would like to thank Ariel Handel, Anna Casaglia, Simone Tulumello, and participants of the seminar series of Urban Transition Hub (ICS-ULisboa) for their comments on earlier versions of the article. Erez Maggor gratefully acknowledges the financial support provided by the Shaine Center for Research in Social Sciences, the Bernard Cherrick Center, and the Israel Galili Institute for the Study of Settlement Policy, Defence and Foreign Affairs. Marco Allegra is grateful for the support provided by the Fundação para a Ciência e a Tecnologia (FCT). While the authors were completing the final draft of this paper Meron Benvenisti, historian, political scientist, and political geographer, passed away. His pioneering work on Israel's policies in the West Bank has been a key source of inspiration for many of those who have struggled to understand the Israeli-Palestinian conflict. In the 1980s, with his associates of the West Bank Data Project, he opened up the field of inquiry in which this paper was born - the authors would like to acknowledge their intellectual debt to this towering figure.

\section{References}

Abreek-Zubiedat, F., \& Nitzan-Shiftan, A. (2020). The right to an urban history: The Gaza Master Plan, 1975-1982. Environment and Planning D, 39(2), 254-270.

Abreek-Zubiedat, F., \& Nitzan-Shiftan, A. (2021). Mediterraneanism in conflict:

Development and settlement of Palestinian refugees and jewish immigrants in Gaza and Yamit. Ethnic and Racial Studies, 44(6), 987-1007.

Abu-Lughod, J. (1982). Israeli settlements in occupied arab lands: Conquest to colony. Journal of Palestine Studies, 11(2), 16-54.

Agnew, J. (1994). The territorial trap: The geographical assumptions of international relations theory. Review of International Political Economy, 1(1), 53-80.

Agnew, J. (2010). Still trapped in territory? Geopolitics, 15(4), 779-784.

Allegra, M. (2016). Habanaliyut shel hakibush: hapolitika shel hapirvur beMa'ale Adumim (The banality of occupation: The politics of suburbia in Ma'ale Adumim). Teoria U'vikoret/Theory and Criticism, (47).

Allegra, M. (2017). Outside Jerusalem-yet so near": Ma'ale Adumim, Jerusalem, and the suburbanization of Israel's settlement policy. In M. Allegra, A. Handel, \& E. Maggor (Eds.), Normalizing occupation. The politics of everyday life in the West Bank settlements (pp. 48-63). Blomington (IN): Indiana University Press.

Allegra, M., \& Handel, A. (2017). Colonizzazione per consenso: la nascita di Ma'ale Adumim (1967-1975) e la politica degli insediamenti israeliana in Cisgiordania. Passato e Presente, (102), 47-67.

Allegra, M., Handel, A., \& Maggor, E. (2021). The Settlements: Past, present, future. In A. Sniver (Ed.), The Routledge Companion to the Israeli-Palestinian Conflict. London and New York: Routledge. 
Allegra, M. (2013). The politics of suburbia: Israel's settlement policy and the production of space in the metropolitan area of Jerusalem. Environment and Planning A, (45), 497-516.

Allegra, M., Handel, A., \& Maggor, E. (2017). Normalizing Occupation. The Politics of Everyday Life in the West Bank Settlements. Bloomington (IN): Indiana University Press.

Allegra, M., Handel, A., \& Maggor, E. (2017). Introduction. In M. Allegra, A. Handel, \& E. Maggor (Eds.), Normalizing Occupation: The Politics of Everyday Life in the West Bank Settlements (pp. 1-20). Bloomington (IN): Indiana University Press.

Allweil, Y. (2020). Neoliberal settlement as violent state project. ACME: An International Journal for Critical Geographies, 19(1), 70-105.

Aran, G. (1991). Jewish Zionist fundamentalism: the Block of the Faithful in Israel (Gush Emunim). In M. E. Marty, \& R. S. Appleby (Eds.), Aran, G. (1991). Jewish Zionist fundamentalism: the Block of the Faithful in Israel (Gush Emunim). Fundamentalism Observed M. E. Marty and R. S. Appleby. Chicago, University of Chicago Press: 265-344. (pp. 265-344). Chicago: University of Chicago Press.

Aran, G. (2013). Kookism: The roots of Gush Emunim, Jewish settlers'subculture, Zionist theology, contemporary messianism. Haifa: Carmel Publishing House.

Aran, G., \& Feige, M. (1987). The movement to stop the withdrawal in Sinai - a sociological perspective. Journal of Applied Behavioral Science, 23(1), 73-87.

Ballvé, T. (2012). Everyday state formation: Territory, decentralization, and the narco landgrab in Colombia. Environment and Planning D, 30(4), 603-622.

Barry, J., \& Agyeman, J. (2020). On belonging and becoming in the settler-colonial city: Co-produced futurities, placemaking, and urban planning in the United States. Journal of Race, Ethnicity and the City, 1(1-2), 22-41.

Bassat, A. B. (2002). In The Israeli economy 1985-1998: From government intervention to market economics. Jerusalem: Israel Democracy Institute.

Benvenisti, M. (1976). Jerusalem, the torn city. Minneapolis: University of Minnesota Press.

Benvenisti, M. (1984). Whe West Bank Data project: A survey of Israel's policies. Washington: American Enterprise Institute for Public Policy Research.

Benvenisti, M. (1986). 1986 report: Demographic, economic, legal, social and political developments in the West Bank. Boulder (CO): Westview Press.

Ben-Shahar, D., Gabriel, S., \& Golan, R. (2019). Ideology, religion, and cheap housing: Israeli settlement of the West Bank. Anderson School of Management, UCLA.

Benvenisti, E. (1989). Legal dualism: The absorption of the occupied territories into Israel. Boulder (CO): Westview Press.

Benvenisti, M., Abu-Zayed, Z., \& Rubinstein, D. (1986). The West Bank handbook: A political lexicon. Jerusalem: The Jerusalem Post.

Benvenisti, M., \& Khayat, S. (1988). The West Bank and Gaza atlas. Jerusalem: West Bank Data Base Project \& The Jerusalem post.

Berda, Y. (2017). Living emergency: Israel's permit regime in the occupied West Bank. Redwood (CA): Stanford University Press.

Braverman, I. (2021). Environmental justice, settler colonialism, and more-than-humans in the occupied West Bank: An introduction. Environment and Planning E, 4(1), 3-27.

Brenner, N. (1997). State territorial restructuring and the production of spatial scale: urban and regional planning in the Federal Republic of Germany, 1960-1990. Political Geography, 16(4), 273-306.

Brenner, N. (2004). New state spaces: Urban restructuring and state rescaling in western Europe. Oxford: Oxford University Press.

Brenner, N., \& Elden, S. (2009). Henri Lefebvre on state, space, territory. International Political Sociology, 3(4), 353-377.

Brenner, N., Jessop, B., Jones, M., \& MacLeod, G. (2003). State space in question. State/ Space: A reader (pp. 1-25). Oxford: Blackwell.

Brenner, N., Peck, J., \& Theodore, N. (2010). Variegated neoliberalization: Geographies, modalities, pathways. Global Networks, 10(2), 182-222.

Cahaner, L. (2017). Between ghetto-politics and geo-politics: Ultra-orthodox settlements in the West bank. In M. Allegra, A. Handel, \& E. Maggor (Eds.), Normalizing occupation: The politics of everyday life in the West Bank settlements (pp. 112-127). Bloomington: Indiana University Press.

Campbell, J. L. (2004). Institutional change and globalization. Princeton \& Oxford: Princeton University Press.

Carmon, N. (2001). Housing policy in Israel: Review, evaluation and lessons. Israel Affairs, 7(4), 181-208.

Cerny, P. G. (1997). Paradoxes of the competition state: The dynamics of political globalization. Government and Opposition, 32(2), 251-274.

Clarno, A. (2017). Neoliberal apartheid: Palestine/Israel and South Africa after 1994. Chicago: University of Chicago Press.

Dahan, M. (2002). The rising of economic inequalities. In A. Ben-Bassat (Ed.), The Israeli economy, 1985-1998 (pp. 610-656). Cambridge (MA): MIT Press.

Dalsheim, J. (2008). Twice removed: Mizrahi settlers in Gush Katif. Social Identities, 14 (5), 535-551.

Dalsheim, J. (2011). Unsettling Gaza: Secular liberalism, radical religion, and the Israeli settlement project. Oxford: Oxford University Press.

Dalsheim, J., \& Harel, A. (2009). Representing settlers. Review of Middle East Studies, 43 (2), 219-238.

Demant, P. (1988). Ploughshares Into Swords: Israeli Settlement Policy in the Occupied Territories, 1967-1977. Amsterdam: Amsterdam University Press.

Efrat, E. (2006). The West Bank and Gaza Strip: A geography of occupation and disengagement. London \& New York: Routledge.

Eldar, A., \& Zertal, I. (2007). Lords of the land: The war over Israel's settlements in the occupied territories, 1967-2007. New York: Nation Books.

Elden, S. (2010). Thinking territory historically. Geopolitics, 15(4), 757-761.

Elor, T., \& Aran, G. (1995). Giving birth to a settlement: Maternal thinking and politicalaction of jewish women on the West Bank. Gender \& Society, 9(1), 60-78.
Faludi, A. (1997). A planning doctrine for Jerusalem? International Planning Studies, 2(1), 83-102.

Farsakh, L. (2005). Palestinian labour migration to Israel: Labour, land and occupation. London: Routledge.

Feige, M. (2001). Jewish settlement of Hebron: The place and the other. GeoJournal, 53 (3), 323-333.

Feige, M. (2002). Do not weep Rachel: Fundamentalism, commemoration and gender in a West Bank settlement. Journal of Israeli History, 21(1-2), 119-138.

Feige, M. (2009). Settling in the hearts: Jewish fundamentalism in the occupied territories. Detroit: Wayne State University Press.

Feige, M. (2013). Soft power: The meaning of home for Gush Emunim settlers. Journal of Israeli History, 32(1), 109-126.

Ford, R. T. (1999). Law's territory (a history of jurisdiction). Michigan Law Review, 97(4), $843-930$.

Fourcade-Gourinchas, M., \& Babb, S. L. (2002). The rebirth of the liberal creed: Paths to neoliberalism in four countries. American Journal of Sociology, 108(3), 533-579.

Friedman, R. (1992). Zealots for Zion: Inside Israel's West Bank settlement movement. New York: Random House.

Gillis, R. (2009). Now they are also settlers: The ethnic morphology of the settlements. Tel Aviv: Tel Aviv University.

Gonen, A. (1995). Between city and suburb. Aldershot: Avebury.

Gordon, N. (2008). Israel's occupation. Berkeley: University of California Press.

Gordon, N., \& Cohen, Y. (2012). Western interests, Israeli unilateralism, and the twostate solution. Journal of Palestine Studies, 41(3), 6-18.

Gorenberg, G. (2006). The accidental empire: Israel and the birth of settlements, 1967-1977. New York: Times Books.

Gourji, A., \& Bassok, M. (2003). Roads in the territories at NIS 10 billion. The Marker, September 29th.

Gradus, Y., Razin, E., \& Krakover, S. (1993). The industrial geography of Israel. London \& New York: Routledge.

Grinberg, L. L. (1991). Split corporatism in Israel. Albany (NY): Stae University of New York Press.

Grosglik, R., Handel, A., \& Monterescu, D. (2021). Soil, territory, land: The spatial politics of settler organic farming in the West Bank, Israel/Palestine. Environment and Planning D. https://doi.org/10.1177/02637758211041121

Gutwein, D (2004). Class aspects of the occupation: Some remarks. Theory and Criticism, $24,202-211$.

Handel, A. (2014). Gated/gating community: The settlement complex in the West Bank. Transactions of the Institute of British Geographers, 39(4), 504-517.

Handel, A., Rand, G., \& Allegra, M. (2015). Wine-washing: Normalization and the geopolitics of terroir in the West Bank's settlements. Environment and Planning A, 47 (6), 1351-1367.

Harel, A. (2017). Beyond Gush Emunim. In Allegra, M., Handel, A., \& Maggor, E. (Eds.), Normalizing occupation: The politics of everyday life in the West Bank settlements (pp. 128-150). Bloomington (IN): Indiana University Press.

Harris, W. (1980). Taking root: Israeli settlements in the West Bank, the Golan, and GazaSinai, 1967-1980. Chichester (UK) \& New York: Research Studies Press.

Harvey, D. (1989). From managerialism to entrepreneurialism: The transformation in urban governance in late capitalism. Geografiska Annaler - Series B: Human Geography, 71(1), 3-17.

Hasson, S., \& Gosenfeld, N. (1980). Israeli frontier settlements: A cross-temporal analysis. Geoforum, 11(4), 315-334.

Hever, S. (2010). The political economy of Israel's occupation. London: Pluto Press.

Hilgers, M. (2012). The historicity of the neoliberal state. Social Anthropology, 20(1), 80-94.

Hirsch-Hoefler, S., Canetti, D., \& Eiran, E. (2016). Radicalizing religion? Religious identity and settlers' behavior. Studies in Conflict \& Terrorism, 39(6), 500-518.

Hirsch-Hoefler, S., \& Mudde, C. (2020). The Israeli settler movement: Assessing and explaining social movement success. Cambridge: Cambridge University Press.

Hirschhorn, S. Y. (2017). City on a hilltop: American Jews and the Israeli settler movement. Cambridge (MA): Harvard University Press.

Inbari, M. (2012). Messianic religious Zionism confronts Israeli territorial compromises. Cambridge: Cambridge University Press.

Isaac, R. J. (1976). Israel divided: Ideological politics in the Jewish State. Baltimore (MD): Johns Hopkins University Press.

Isaac, R. K. (2018). Tourism as a tool for colonisation, segregation, displacement and dispossession. Routledge Handbook on Tourism in the Middle East and North Africa.

Jessop, B. (2002). The future of the capitalist state. Cambridge: Polity Press.

Kratsman, M., \& Ginsburg, R. (2017). Educating architecture. In M. Allegra, A. Handel, \& E. Maggor (Eds.), Normalizing occupation: The politics of everyday life in the West Bank settlements (pp. 64-71). Bloomington (IN): Indiana University Press.

Kristal, T. (2013). Slicing the pie: State policy, class organization, class integration, and Labor's share of Israeli national income. Social Problems, 60(1), 100-127.

Levi-Faur, D. (1998). The developmental state: Israel, South Korea, and taiwan compared. Studies in Comparative International Development, 33(1), 65-93.

Lustick, I. (1988). For the land and the Lord: Jewish fundamentalism in Israel. New York: Council on Foreign Relations.

Lustick, I. (1993). Unsettled states, disputed lands: Britain and Ireland, France and Algeria, Israel and the West Bank-Gaza. Ithaca (NY): Cornell University Press.

Maggor, E. (2015). State, market and the Israeli settlements: The ministry of housing and the shift from messianic outposts to urban settlements in the early 1980s. Israeli Sociology, 16(2), 140-167.

Maggor, E. (2021). Sources of state discipline: lessons from Israel's developmental state, 1948-1973. Socio-Economic Review, 19(2), 553-581. 
Maman, D., \& Rosenhek, Z. (2012). The institutional dynamics of a developmental state: Change and continuity in state-economy relations in Israel. Studies in Comparative International Development, 47(3), 342-363.

Margalit, T. (2014). Multi-spot zoning: A chain of public-private development ventures in Tel Aviv. Cities, 37, 73-81.

Maron, A. (2015). Trends and processes of privatization in social services in Israel. In I. Galnoor, A. Paz-Fuchs, \& N. Zion (Eds.), Privatization policy in Israel: State responsibility and the boundaries between the public and the private (pp. 137-187). Jerusalem: Jerusalem: Van Leer Institute).

Maron, A., \& Shalev, M. (2017). Neoliberalism as a state project: Changing the political economy of Israel. Oxford: Oxford University Press.

McGonigle, I. A. N. (2019). In vino veritas? Indigenous wine and indigenization in Israeli settlements. Anthropology Today, 35(4), 7-12.

Monterescu, D., \& Handel, A. (2020). Terroir and territory on the colonial frontier: Making New-Old World wine in the Holy Land. Comparative Studies in Society and History, 62(2), 222-261.

Newman, D. (1985). The impact of Gush Emunim: Politics and settlement in the West Bank. London: Croom Helm.

Newman, D. (1989). Civilian and military presence as strategies of territorial control: The Arab-Israel conflict. Political Geography Quarterly, 8(3), 215-227.

Newman, D. (1996). The territorial politics of exurbanization: Reflections on 25 years of Jewish settlement in the West Bank. Israel Affairs, 3(1), 61-85.

Newman, D., \& Hermann, T. (1992). A Comparative-Study of Gush Emunim and Peace Now. Middle Eastern Studies, 28(3), 509-530.

Newman, D., \& Portugali, J. (1987). Spatial interaction between Israelis and Palestinians in the West Bank and the Gaza Strip. New York: Ford Foundation.

Painter, J. (2010). Rethinking territory. Antipode, 42(5), 1090-1118.

Paz-Fuchs, A., Mandelkern, R., \& Galnoor, I. (2018). The privatization of Israel. New York: Palgrave Macmillan.

Paz-Fuchs, A., \& Ronen, Y. (2017). Integrated or segregated? Israeli-Palestinian employment relations in the settlements. In M. Allegra, A. Handel, \& E. Maggor (Eds.), Normalizing occupation: The politics of everyday life in The West Bank settlements (pp. 172-192). Bloomington (IN): Indiana University Press.

Pedahzur, A., \& McCarthy, H. (2015). Against all odds - the paradoxical victory of the West bank settlers: Interest groups and policy enforcement. Israel Affairs, 21(3), 443-461.

Pedahzur, A., \& Perliger, A. (2009). Jewish terrorism in Israel. New York: Columbia University Press.

Peled, Y., \& Shafir, G. (2002). Being Israeli: The dynamics of multiple citizenship. Cambridge: Cambridge University Press.

Porter, L., \& Yiftachel, O. (2019). Urbanizing settler-colonial studies: Introduction to the special issue. Settler Colonial Studies, 9(2), 177-186.

Portugali, J. (1991). Jewish settlement in the occupied territories Israel settlement structure and the Palestinians. Political Geography Quarterly, 10(1), 26-53.

Prasad, M. (2006). The politics of free markets: The rise of neoliberal economic policies in Britain, France, Germany, and the United States. Chicago: University of Chicago Press.

Pullan, W., \& Yacobi, H. (2017). Jerusalem's colonial space as paradox: Palestinians living in the settlements. In M. Allegra, A. Handel, \& E. Maggor (Eds.), Normalizing occupation: The politics of everyday life in the West Bank settlements (pp. 193-210). Bloomington: Indiana University Press.

Purcell, M., \& Nevins, J. (2005). Pushing the boundary: State restructuring, state theory, and the case of US-Mexico border enforcement in the 1990s. Political Geography, 24 (2), 211-235.

Rabie, K. (2021). Palestine is throwing a party and the whole world is invited: Capital and state building in the West Bank. Durham (NC) \& London: Duke University Press.

Ranta, R. (2015). Political decision making and non-decisions: The case of Israel and the occupied territories. New York: Palgrave Macmillan.

Rosenhek, Z. (1999). The exclusionary logic of the welfare state: Palestinian citizens in the Israeli welfare state. International Sociology, 14(2), 195-205.

Razin, E. (1990). Urban economic development in a period of local initiative: competition among towns in Israel's southern coastal plain. Urban Studies, 27(5), 685-703.

Rokem, J., \& Allegra, M. (2016). Planning in turbulent times: Exploring planners' agency in Jerusalem. International Journal of Urban and Regional Research, 40(3), 640-657.

Rubin, D. (2015). Haredi settlers: The non-Zionist Jewish settlers of the West Bank. In E. Isin (Ed.), Citizenship after orientalism (pp. 70-98). London: Palgrave Macmillan.

Schwake, G. (2020a). The Americanisation of Israeli housing practices. The Journal of Architecture, 25(3), 295-316.
Schwake, G. (2020b). The bourgeoisification of the Green-Line: The new Israeli middleclass and the Suburban Settlement. Political Geography, 82, 102223.

Schwake, G. (2021a). The community settlement: a neo-rural territorial tool. Planning Perspectives, 36(2), 237-257.

Schwake, G. (2021b). An officer and a bourgeois: Israeli military personnel, suburbanization and selective privatization. Planning Perspectives, 36(1), 183-194.

Schwake, G. (2020c). Settle and Rule: the evolution of the Israeli national project. Architecture and Culture, 8(2), 350-371.

Schwake, G. (2021c). Supply-side territoriality: reshaping a geopolitical project according to economic means. Space and Polity, 25(1), 75-96.

Schweid, J. (1986). The planning of Jerusalem before and after 1967: Attitudes toward uncertainty. In D. Morley, \& A. Shachar (Eds.), Planning in turbulence (pp. 107-113). Jerusalem: Magnes Press.

Shachar, A. (1998). Reshaping the map of Israel: A new national planning doctrine. The Annals of the American Academy of Political and Social Science, 555(1), 209-218.

Shahak, I., \& Mezvinsky, N. (1999). Jewish fundamentalism in Israel. London: Pluto Press.

Shalev, M. (1992). Labour and the political economy in Israel. Oxford: Oxford University Press.

Shalev, M. (1998). Have globalization and liberalization "normalized" Israel's political economy? Israel Affairs, 5(2-3), 121-155.

Shenhav, Y. A. (2012). Beyond the two-state solution: A Jewish political essay. Cambridge: Polity Press.

Shezaf, H. (2020). Highways to annexation: Across the West bank, Israel is bulldozing a bright future for Jewish settlers. Ha'aretz, December 11 th.

Shlay, A. B., \& Rosen, G. (2010). Making place: The shifting green line and the development of "greater" metropolitan Jerusalem. City \& Community, 9(4), 358-389.

Shoked, N. (2019). Rabbis, architects, and the design of ultra-orthodox city-settlements. Social Housing in the Middle East: Architecture, Urban Development, and Transnational Modernity, 241-266.

Shoked, N. (2020). Design and contestation in the jewish settlement of Hebron, 1967-87. Journal of the Society of Architectural Historians, 79(1), 82-102.

Siegman, J. A. (2018). "Super-Israel": The politics of Palestinian labor in a settler supermarket. Journal of Palestine Studies, 47(4), 9-29.

Sivan, E. (1995). The enclave culture. In M. E. Marty, \& E. S. Appleby (Eds.), Fundamentalisms comprehended (pp. 11-68). Chicago \& London: University of Chicago Press.

Sprinzak, E. (1991). The ascendance of Israel's radical right. Oxford: Oxford University Press.

Tabar, L. (2007). Memory, agency, counter-narrative: Testimonies from Jenin refugee camp. Critical Arts: A Journal of South-North Cultural Studies, 21(1), 6-31.

Taub, G. (2010). The settlers: And the struggle over the meaning of Zionism. New Haven: Yale University Press.

Vickery, M. (2017). Employing the enemy: The story of Palestinian labourers on Israeli settlements. London: Zed Books.

Weiss, L. (1998). The myth of the powerless state. Ithaca (NY): Cornell University Press.

Weisburd, D. (1989). Jewish settler violence: Deviance as social reaction. University Park: Pennsylvania State University Press.

Weiss, H. (2009). Review: Settling in the hearts: Jewish fundamentalism in the occupied territories by Michael Feige. Cultural Anthropology, 24(4), 755-757.

Weiss, H. (2011). Immigration and West Bank settlement normalization. PoLAR: Political and Legal Anthropology Review, 34(1), 112-130.

Weiss, H. (2017). Embedded politics in a West Bank settlement. In M. Allegra, A. Handel, \& E. Maggor (Eds.), Normalizing occupation. The politics of everyday life in the West Bank settlements (pp. 75-91). Bloomington (IN): Indiana University Press.

Weizman, E. (2007). Hollow land Israel's architecture of occupation. London and New York: Verso.

Yacobi, H., \& Pullan, W. (2014). The geopolitics of neighbourhood: Jerusalem's colonial space revisited. Geopolitics, 19(3), 514-539.

Yacobi, H., \& Pullan, W. (2017). Jerusalem's colonial space as paradox: Palestinians living in the settlements. In M. Allegra, A. Handel, \& E. Maggor (Eds.), Normalizing cccupation: The politics of everyday life in the West Bank settlements (pp. 193-210). Bloomington (IN): Indiana University Press.

Yiftachel, O. (2003). Settlements as a reflex action. In R. Segal, \& E. Weizman (Eds.), A civilian occupation. The politics of Israeli architecture (pp. 32-39). London: Verso.

Yiftachel, O. (2006). Ethnocracy: Land and identity politics in Israel/Palestine. Philadelphia: University of Pennsylvania Press.

Yiftachel, O. (2016). The Aleph—Jerusalem as critical learning. City, 20(3), 483-494. 